\title{
Klasifikasi Jenis Buah Apel Menggunakan Metode Orde 1 dengan Algoritma Multi Support-Vector Machines
}

\author{
Rizky Ade Safitri ${ }^{1}$, Siti Nurdiani $^{2}$, Dwiza Riana $^{3}$, Sri Hadianti ${ }^{4}$ \\ ${ }^{1}$ STMIK Nusa Mandiri Jakarta \\ e-mail: rrizkyadesafitri@gmail.com \\ ${ }^{2}$ STMIK Nusa Mandiri Jakarta \\ e-mail: sitinurdiani18@gmail.com \\ ${ }^{3}$ STMIK Nusa Mandiri Jakarta \\ e-mail: dwiza@nusamandiri.ac.id \\ ${ }^{4}$ STMIK Nusa Mandiri Jakarta \\ e-mail: sri.shv@nusamandiri.ac.id
}

Cara Sitasi: Safitri, R. A., Nurdiani, S., Riana, D., \& Hadianti, S. (2019). Klasifikasi Jenis Buah Apel Menggunakan Metode Orde 1 dengan Algoritma Multi Support-Vector Machines. Paradigma - Jurnal Komputer dan Informatika, 21(2), 167-172. doi:10.31294/p.v21i2.6526

\begin{abstract}
Apples are a type of fruit which has a variety of colors on its own skin, some are red, green and yellow. Apples also have many types and are easily found in the country and abroad. Each type of apple has different characteristics so that different opinions will be obtained by each individual which causes a different level of accuracy. Current classification technology can be used to assist the sorting process. This research uses first order method with multi SVM algorithm which aims to recognize apple patterns using texture analysis on grayscale images and color feature extraction on color images. The results of the feature extraction will be input for multi SVM to classify the types of apples. The data used in this study were of 50 images, consisting of 35 training data images and 15 test data. The results of this method's accuracy reached an accuracy rate of only $86 \%$.
\end{abstract}

Keywords : Apples, Classifications, SVM

\section{PENDAHULUAN}

Pengenalan pola pada citra sangat meluas dan banyak dikembangkan dengan beberapa jumlah pendekatan selama bertahun-tahun hingga kini. Pengenalan pola salah satu metode yang bekerja untuk menemukan pola pada data yang menunjukkan satu informasi tertentu dan juga memiliki prinsip kerja yang membandingkan kemiripan suatu benda pada tingkat presentase tertentu berdasarkan informasi yang sudah pernah diperoleh. Apel merupakan jenis buah-buahan dimana memiliki beragam jenis warna pada kulitnya tersendiri, ada yang berwarna merah, hijau maupun warna kuning. Buah apel ini memiliki nama ilmiah yaitu Malus Domestica. Buah apel juga memiliki banyak jenis ada apel manalagi, apel red delicious, apel golden, apel granny, apel crimson, apel rome beauty, apel anna, apel gala, apel princess noble dan masih banyak lagi. Maka dari banyaknya jenis-jenis buah apel tersebut tentu akan sedikit menyulitkan untuk membedakan antara buah apel red delicious dengan buah apel granny serta buah apel golden dan juga bapel crimson secara pada ciri-ciri masingmasing buah tersebut hampir banyak memiliki kesamaan ciri namun tetap terdapat perbedaan antara apel yang satu dengan apel lainnya.

Dari jenis-jenis buah apel tersebut selain dapat dikonsumsi secara mentah / langsung, maka buahbuahan tersebut dapat dikonsumsi dengan mengolahnya terlebih dahulu yaitu seperti manisan, keripik buah apel dan minuman. Buah apel sendiri memiliki banyak nutrisi dan berbagai macam vitamin diantaranya lemak, serta, energi, karbohidrat, protein vitamin $\mathrm{C}$, vitamin $\mathrm{A}$, vitamin B2, vitamin B1 dan masih banyak lagi (Ciputra, 2018). Teknologi saat ini memungkinkan untuk melakukan klasifikasi citra digital. Secara umum tahapan dalam proses klasifikasi citra digital yaitu 
akusisi citra, pra pengolahan citra, ekstraksi ciri/ fitur, pelatihan, pengujian dan pengukuran akurasi. Klasifikasi bertujuan untuk mengelompokkan objek menjadi kelas tertentu berdasarkan nilai atribut yang berkaitan dengan objek yang diamati tersebut.

Penelitian ini bertujuan untuk pengenalan pola buah apel menggunakan analisis tekstur pada citra grayscale dan ekstraksi fitur warna pada citra warna. Unsur citra grayscale memiliki unsur-unsur mean, entropi, variance, skwenees, kurtosis. Hasil ekstrasi fitur akan menjadi input bagi multi SVM untuk mengklasifikasikan jenis apel. Data yang digunakan adalah image buah apel yang terdiri dari 50 buah foto dari 5 jenis apel (masing-masing jenis memiliki 10 image).

\section{Kajian Literatur}

\section{Ekstraksi Ciri Statistik Orde 1}

Ekstraksi ciri merupakan metode pengambilan ciri yang didasarkan pada karakteristik histogram citra.Histogram menunjukkan probabilitas kemunculan nilai derajat keabuan piksel pada suatu citra (Permadi \& Murinto, 2015). Analisis citra pada dasarnya melibatkan ekstraksi ciri,segmentasi, dan klasifikasi. Ekstraksi ciri adalah proses mengambil ciri-ciri yang terdapat pada objek di dalam citra untuk mengenali objek tersebut. Ekstraksi ciri merupakan langkah awal dalam melakukan klasifikasi dan interpretasi citra. Proses ini berkaitan dengan kuantisasi karakteristik citra ke dalam sekelompok nilai ciri yang sesuai. Ciri-ciri umum yang digunakan untuk mengenali satu atau beberapa objek di dalam citra adalah ukuran, posisi atau lokasi, dan orientasi atau sudut kemiringan objek terhadap garis acuan yang digunakan. Salah satu metode yang digunakan pada ekstraksi ciri adalah ekstraksi ciri statistik orde pertama (Nurhayati, 2015). Dari nilai-nilai pada histogram yang dihasilkan, dapat dihitung beberapa parameter ciri, antara lain adalah mean, variance, skewness, kurtosis, dan entropy.

1.1. Ciri Mean ( $\mu$ ) Menunjukkan ukuran dispersi dari suatu citra

$$
\mu=\sum_{\mathrm{n}=0}^{\mathrm{N}} \mathrm{f}_{\mathrm{n}} \mathrm{p}\left(\mathrm{f}_{\mathrm{n}}\right)
$$

Dimana $: \mathrm{f}_{\mathrm{n}}=$ nilai intensitas keabuan $\mathrm{P}\left(\mathrm{f}_{\mathrm{n}}\right)=$ nilai histogram

1.2. Ciri Variance $(\sigma 2)$ Menunjukkan variasi elemen pada histogram dari suatu citra

$$
\sigma^{2}=\sum_{n=0}^{N}\left(f_{n}-\mu\right)^{2} p\left(f_{n}\right)
$$

Dimana $: \mathrm{f}_{\mathrm{n}}=$ nilai intensitas keabuan

$$
\mu=\text { nilai mean }
$$

$\mathrm{P}\left(\mathrm{f}_{\mathrm{n}}\right)=$ nilai histogram

$$
\alpha_{3}=\frac{1}{\sigma^{3}} \sum_{\mathrm{n}=0}^{\mathrm{N}}\left(\mathrm{f}_{\mathrm{n}}-\mu\right)^{3} \mathrm{p}\left(\mathrm{f}_{\mathrm{n}}\right)
$$

Dimana $: \mathrm{a}^{3}=$ standar deviasi dari nilai intensitas keabuan $\mathrm{f}_{\mathrm{n}}=$ nilai intensitas keabuan $\mu=$ nilai mean $\mathrm{P}\left(\mathrm{f}_{\mathrm{n}}\right)=$ nilai histogram

1.4. Ciri Kurtosis (a4 ) Menunjukkan tingkat keruncingan relatif kurva histogram dari suatu citra

$$
\alpha_{4}=\frac{1}{\sigma^{4}} \sum_{n=0}^{N}\left(f_{n}-\mu\right)^{4} p\left(f_{n}\right)-3
$$

Dimana : $\mathrm{a}^{4}=$ standar deviasi dari nilai intensitas keabuan $\mathrm{f}_{\mathrm{n}}=$ nilai intensitas keabuan $\mu=$ nilai mean $\mathrm{P}\left(\mathrm{f}_{\mathrm{n}}\right)=$ nilai histogram

1.5. Ciri Entropy $(\mathrm{H})$ Menunjukkan ukuran ketidakaturan bentuk dari suatu citra

$$
H=-\sum_{n=0}^{N} p\left(f_{n}\right) \cdot{ }^{2} \log p\left(f_{n}\right)
$$

Dimana : $\mathrm{p}\left(\mathrm{f}_{\mathrm{n}}\right)=$ nilai histogram

\section{Support Vector Machine}

Support vector machine merupakan salah satu metode yang digunakan dalam mengklasifikasikan suatu citra dengan konsep dasar yang menggunakan sebuah fungsi linear atau hyperlane yang dapat memisahkan data latih kedalam dua kelas dengan memaksimalkan margin diantara kedua kelas tersebut [8]. Jadi dapat dikatakan tujuan dalam SVM adalah berusaha untuk menemukan hyperlane atau fungsi pemisah (klasifier) yang optimal yang dapat memisahkan dua set data dari dua kelas yang berbeda [9]. Hyperplane pemisah terbaik antara kedua kelas dapat ditemukan dengan mengukur margin hyperplane tersebut dan mencari titik maksimalnya. Margin adalah jarak antara hyperplane tersebut dengan pattern terdekat dari masing masing kelas. Pattern terdekat inilah yang disebut support vector. Garis antar pattern menunjukan hyperplane yang terbaik yaitu yang terletak tepat pada tengah tengah kedua kelas [10]. Support vector machine merupakan golongan supervised learning yaitu memiliki proses pembelajaran yang akan menghasilkan suatu fungsi pemisah dari input-output berdasarkan sejumlah data latih [8](Ahmad, Hidayat, \& Darana, 2017)

\section{METODE PENELITIAN}

\section{Perancangan Pengolahan Citra}

Pengolahan citra yang dirancang dapat dinyatakan dalam gambar 1 dibawah ini:

\subsection{Ciri Skewness (a3) Menunjukkan tingkat} kemencengan relatif kurva histogram dari suatu citra 


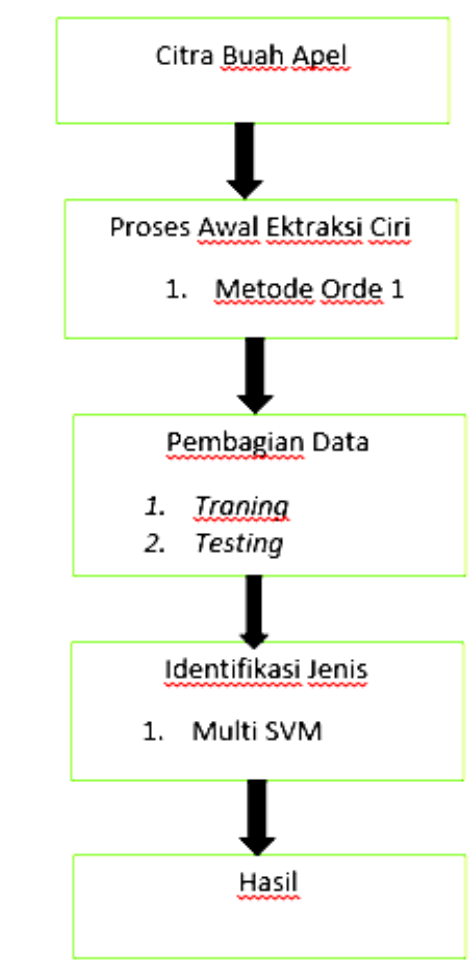

Gambar 1. Perancangan Pengolahan Citra

\section{Ekstraksi Fitur dengan Orde 1}

Ekstraksi fitur citra buah apel bertujuan untuk memperoleh ciri dari citra apel tersebut menggunakan metode Orde 1 yang akan menampilkan hasil berupa angka. Pada penelitian ini menggunakan 5 fitur ekstraksi meliputi nilai: Mean, Entropy, Variance, Skewness, dan Kurtosis.

\section{Data Latih dan Data Uji}

Citra buah apel berjumlah 50 buah data terbagi atas 2 jenis bagian, yitu data training sebanyak 35 buah dan data tesing sebanyak 15 buah. Citra apel terbagi atas 5 jenis, yaitu Apel Grany, Apel Red, Apel Crimson, Apel Delicious dan Apel Golden.

\section{Klasifikasi dengan Algoritma Multi SVM}

\subsection{Akurasi Percobaan}

Hasil dari penelitian ini akan diukur akurasinya untuk menilai seberapa besar kinerja sistem dalam mengklasifikasi jenis buah apel. Akurasi dihitung berdasarkan data Tesing atau data yang di uji pada 15 data yang terdiri atas 3 buah data dari masing-masing jenis apel.Hasil penyebaran kesalahan klasifikasi digunakan confusion matriks.

$$
\text { Akurasi }=\frac{\text { Jumlah Klasifikasi yang benar x } 100 \%}{\text { Jumlah semua data }}
$$

\section{HASIL DAN PEMBAHASAN}

\section{Akuisisi Data}

Sistem identifikasi jenis buah apel dapat diuji setelah sistem itu dilatih dahulu. Pengujian sistem dilakukan dengan cara masukan citra buah (image) yang belum dikenali atau baru yang belum pernah dipakai di pelatihan (training). Pada sistem identifikasi buah apel ini data dibagi menjadi dua bagian, yaitu:

1. Data citra pelatihan (training) yang digunakan untuk mengetahui pola standar masing-masing buah apel.

2. Data citra pengujian (testing) yang selanjutnya akan digunakan sebagai data uji untuk kerja sistem dalam mengidentifikasi jenis buah apel.

Citra yang digunakan sebagai standar tidak digunakan dalam pengujian. Dibawah ini merupakan contoh citra yang akan digunakan pada sistem identifikasi jenis buah apel:

Tabel 1. Sumber Data Jenis Buah Apel

\begin{tabular}{|c|c|c|c|c|}
\hline $\begin{array}{c}\text { Jenis } \\
\text { Apel }\end{array}$ & $\begin{array}{c}\text { Jumlah } \\
\text { Citra }\end{array}$ & Standar & Pengujian & Format \\
\hline $\begin{array}{c}\text { Apel } \\
\text { Grany }\end{array}$ & 10 & 7 & 3 & \\
\cline { 1 - 4 } $\begin{array}{c}\text { Apel } \\
\text { Red }\end{array}$ & 10 & 7 & 3 & \\
\hline $\begin{array}{c}\text { Apel } \\
\text { Crimson }\end{array}$ & 10 & 7 & 3 & \multirow{2}{*}{$*$ JPG } \\
\cline { 1 - 3 } $\begin{array}{c}\text { Apel } \\
\text { Delic }\end{array}$ & 10 & 7 & 3 & \\
\cline { 1 - 3 } $\begin{array}{c}\text { Apel } \\
\text { Golden }\end{array}$ & 10 & 7 & 3 & \\
\hline
\end{tabular}

Beberapa contoh citra yang digunakan pada penelitian ini ditunjukkan pada gambar berikut:

a. Apel Delicious

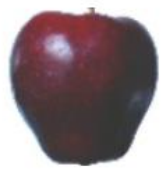

Gambar 2. Citra Asli Apel Delicius

b. Apel Golden

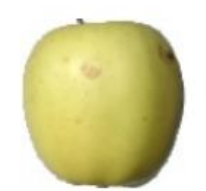

Gambar 3. Citra Asli Apel Golden 
c. Apel Crimson

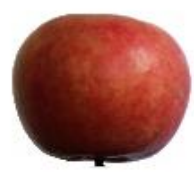

Gambar 4. Citra Asli Apel Crimson

d. Apel Grany

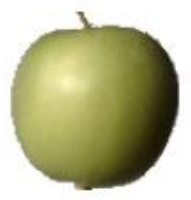

Gambar 5. Citra Asli Apel Grany

e. Apel Red

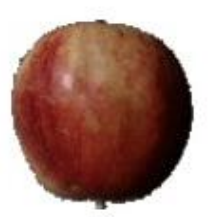

Gambar 6. Citra Asli Apel Red

\section{Hasil Pengujian}

\subsection{Pemrosesan Awal}

Pada proses ini masing-masing citra dikonversi dari citra asli ke dalam citra bentuk keabuan (grayscale). Pengkonversian dilakukan dengan Metode Orde 1. Hasil dari pengkonversian citra bisa dilihat pada gambar dibawah ini:

a. Apel Delicious
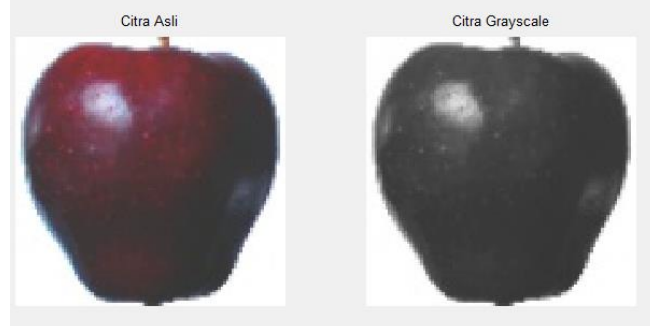

b. Apel Golden

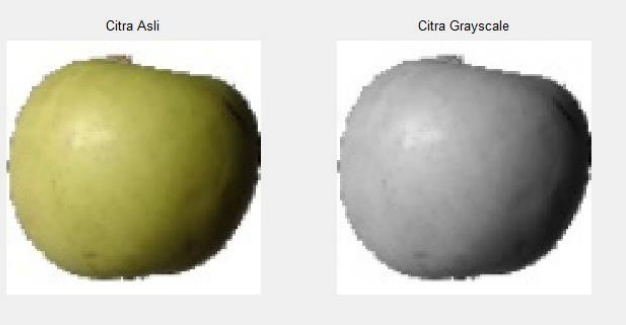

c. Apel Crimson
Citra Asli

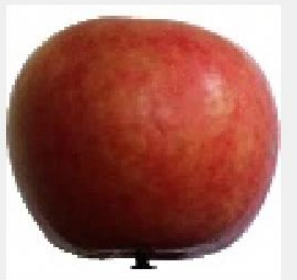

Citra Grayscale

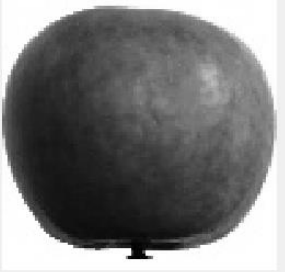

d. Apel Grany

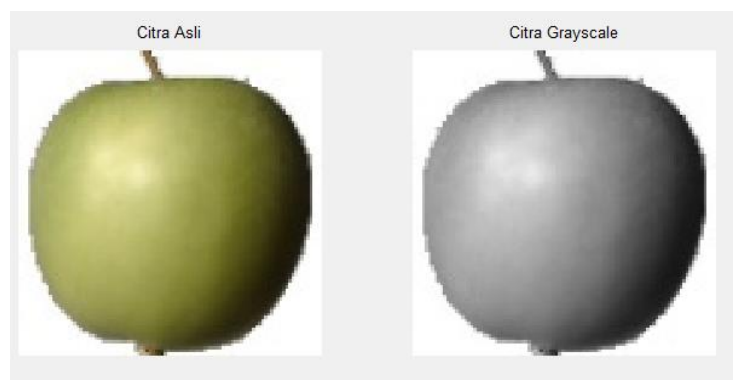




\section{e. Apel Red}

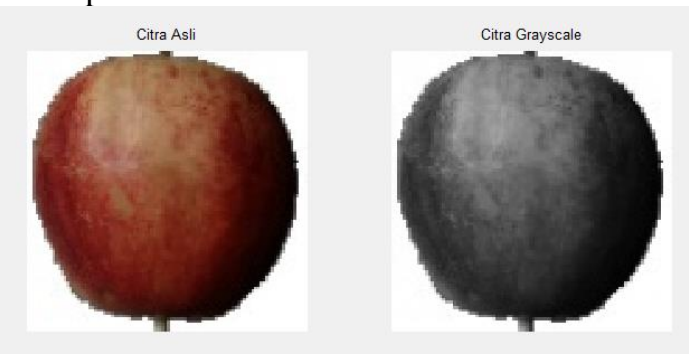

\subsection{Pengujian Sistem Identifikasi}

Pengujian kerja sistem merupakan proses yang penting untuk memastikan apakah sistem dapat diaplikasikan. Dengan Metode Multi SVM untuk mengklasifikasikan jenis apel telah diterapkan. Hasil dari Eksperimen dari pengujian masing-masing Data Training dan Data Testing tersebut bisa dilihat pada table dan gambar di bawah ini :

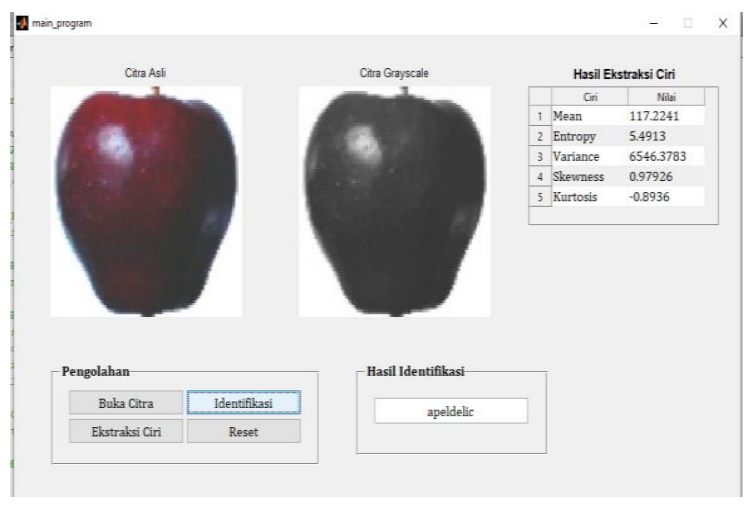

Gambar 12. Hasil Uji Identifikasi Apel dengan Algoritma Multi SVM

Tabel 2. Hasil Uji Data Training Identifikasi Buah Apel

\begin{tabular}{|c|c|c|c|c|c|}
\hline Nama Apel & Mean & Entropy & Variance & Skewness & Kurtosis \\
\hline Apel Grany 1 & 1668319 & 67979 & 50732000 & 0,23 & $-0,98$ \\
\hline Apel Grany 2 & 1670568 & 67902 & 50875032 & $-0,2886$ & $-0,98438$ \\
\hline Apel Grany 3 & 166878 & 67968 & 51093319 & $-0,29547$ & $-0,98415$ \\
\hline Apel Grany 4 & 1670163 & 68048 & 5124627 & $-0,29649$ & $-0,9874$ \\
\hline Apel Grany 5 & 1619444 & 67813 & 55228341 & $-0,30141$ & $-1,08$ \\
\hline Apel Grany 6 & 161873 & 67617 & 55302749 & $-0,25$ & $-1,08$ \\
\hline Apel Grany 7 & 1599428 & 68079 & 55459185 & $-0,24714$ & $-1,1226$ \\
\hline Apel Red 1 & 1152509 & 67433 & 75698179 & 0,64566 & -16439 \\
\hline Apel Red 2 & 1173039 & 67777 & 76181361 & 0,56194 & $-1,1115$ \\
\hline Apel Red 3 & 1155168 & 67553 & 75543729 & 0,63813 & $-1,049$ \\
\hline Apel Red 4 & 1145629 & 67633 & 7538119 & 0,66737 & $-1,02$ \\
\hline Apel Red 5 & 1148384 & 67498 & 75502289 & 0,66104 & $-1,0282$ \\
\hline Apel Red 6 & 1145677 & 67566 & 75297012 & 0,6646 & $-1,0172$ \\
\hline Apel Red 7 & 1151001 & 67323 & 75798443 & 0,65927 & $-1,0399$ \\
\hline Apel Crimson 1 & 1224977 & 66525 & 72.285 .638 & 0,60038 & $-1,1415$ \\
\hline Apel Crimson 2 & 1215458 & 66563 & 71365161 & 0,62674 & $-1,0967$ \\
\hline Apel Crimson 3 & 1197003 & 66911 & 69498267 & 0,67997 & $-1,0132$ \\
\hline Apel Crimson 4 & 1222063 & 66651 & 71715267 & 0,61521 & $-1,1235$ \\
\hline Apel Crimson 5 & 1214269 & 66567 & 71090193 & 0,63395 & $-1,0899$ \\
\hline Apel Crimson 6 & 1204146 & 66711 & 70192089 & 0,661 & $-1,0441$ \\
\hline Apel Crimson 7 & 1202519 & 66819 & 7011255 & 0,66534 & $-1,0412$ \\
\hline & & & & & \\
\hline
\end{tabular}

\begin{tabular}{|c|c|c|c|c|c|} 
Apel Crimson 7 & 1202519 & 66819 & 7011255 & 0,66534 & $-1,0412$ \\
\hline Apel Delic 1 & 1169304 & 54912 & 65385198 & 0,98578 & $-0,88058$ \\
\hline Apel Delic 2 & 1174931 & 55212 & 65629706 & 0,95479 & $-0,92225$ \\
\hline Apel Delic 3 & 1199412 & 54937 & 67512221 & 0,88404 & $-1,0608$ \\
\hline Apel Delic 4 & 1200072 & 54958 & 67465617 & 0,88717 & $-1,0631$ \\
\hline Apel Delic 5 & 1198064 & 55266 & 67120283 & 0,88529 & $-1,0557$ \\
\hline Apel Delic 6 & 1997098 & 55229 & 67120288 & 0,88809 & $-1,0501$ \\
\hline Apel Delic 7 & 1187234 & 55312 & 66552015 & 0,91289 & $-1,0033$ \\
\hline Apel Golden 1 & 1897544 & 68025 & 27053569 & $-0,49206$ & $-0,61169$ \\
\hline Apel Golden 2 & 1881198 & 68608 & 25197748 & $-0,57228$ & $-0,43121$ \\
\hline Apel Golden 3 & 1890545 & 68465 & 24037495 & $-0,53404$ & $-0,29926$ \\
\hline Apel Golden 4 & 1644496 & 67969 & 46732361 & $-0,24918$ & $-0,81722$ \\
\hline Apel Golden 5 & 1625054 & 68811 & 45300348 & $-0,21093$ & $-0,76574$ \\
\hline Apel Golden 6 & 1621198 & 6911 & 44199186 & $-0,15965$ & $-0,77797$ \\
\hline Apel Golden 7 & 1620241 & 68579 & 46329315 & 0,2258 & $-0,80926$ \\
\hline & & & & &
\end{tabular}

Tabel diatas merupakan hasil uji ekstraksi ciri dengan metode Orde 1 dari 35 data training buah apel. Hasil dari ekstraksi ciri dapat dilihat dari nilai keluaran seperti mean, entropy, variance, skewness, dan kurtosis.Nilai diatas akan dijadikan sebagai acuan untuk mengklasifikasikan 15 buah apel testing yang sesuai dengan standar nilai.

Tabel. 3 Hasil Uji Data Testing Identifikasi Buah Apel

\begin{tabular}{|c|c|c|c|c|c|c|}
\hline Nama Apel & Mean & Entropy & Variance & Skermess & Kurtosis & Hasil Identifikasi \\
\hline Apel Grany 1 & 166,9061 & 67833 & 49963089 & $-0,28$ & $-0,98$ & Apel Grany \\
\hline Apel Grany 2 & 166,6747 & 67958 & 50073133 & $-0,27723$ & $-0,97501$ & Apel Grany \\
\hline Apel Grany 3 & 166,9677 & 67885 & 5033131 & $-0,2861$ & $-0,97758$ & Apel Grany \\
\hline Apel Red 1 & 117,1265 & 67583 & 76176681 & $-0,59959$ & $-1,1029$ & Apel Red \\
\hline Apel Red 2 & 116,7113 & 67613 & 7600794 & $-0,60879$ & $-1,09$ & Apel Red \\
\hline Apel Red 3 & 116,4547 & 676 & 75922497 & 0,61605 & $-1,08$ & Apel Red \\
\hline Apel Crimson 1 & 122,7493 & 66339 & 72271416 & 0,59301 & $-1,1447$ & Apel Crimson \\
\hline Apel Crimson 2 & 123,0286 & 66448 & 72445038 & 0,58753 & $-1,1563$ & Apel Crimson \\
\hline Apel Crimson 3 & 122,2314 & 66591 & 72193023 & 0,60464 & $-1,1333$ & Apel Crimson \\
\hline Apel Delic1 & 117,2241 & 54913 & 65463783 & 0,97926 & $-0,8936$ & Apel Delic \\
\hline Apel Delic2 & 117,2027 & 55248 & 654172 & 0,96645 & $-0,89979$ & Apel Delic \\
\hline Apel Delic3 & 132,5087 & 52124 & 77533179 & 0,56664 & $-1,5785$ & Apel Delic \\
\hline Apel Golden 1 & 189,1708 & 68298 & 27596918 & 0,50993 & $-0,60249$ & Apel Golden \\
\hline Apel Golden 2 & 188,7163 & 68298 & 24125652 & 0,53645 & $-0,2954$ & Apel Golden \\
\hline Apel Golden 3 & 1.671 .559 & 6.767 & 50.908.308 & -0.35442 & -0.92078 & Apel Grany \\
\hline
\end{tabular}

Berdasarkan tabel.3 Hasil Identifikasi dan Klasifikasi dari 15 buah apel menyatakan benar terdapat 3 buah Jenis Apel Grany, 3 buah Jenis Apel Red, 3 buah Jenis Apel Crimson , 3 buah Jenis Apek Delic serta 3 buah Jenis Apel Golden namun ada satu yang terklasifikasi ke Jenis Apel Grany. Karena terdapat satu kesalahan dalam klasifikasi ini menjadikan Algoritma Multi SVM memiliki tingkat akurasi hanya sebesar $86,6667 \%$.

\section{KESIMPULAN}

Berdasarkan hasil uji coba yang telah dilakukan pada penelitian ini, terbukti bahwa Algoritma Multi SVM dapat digunaka untuk mengklasifikasi jenis buah apel. Namun tingkat akurasi hanya sebesar 86,6667 \%. Maka untuk penelitian berikut nya bisa dikembangkan dengan algoritma dan metode yang lain agar dapat 
memaksimalkan proses prapengolahan dan ekstrasi ciri citra serta meningkatkan tingkat akurasi.

\section{REFERENSI}

Ahmad, haidar maghrifa, Hidayat, D. I. B., \& Darana, P. D. I. S. (2017). IDENTIFIKASI DAN KLASIFIKASI KEMURNIAN SUSU SAPI BERDASARKAN PEMROSESAN SINYAL VIDEO MENGGUNAKAN METODE GABOR WAVELET DAN SUPPORT VECTOR MACHINE IDENTIFICATION AND CLASSIFICATION OF COW MILK PURENESS BASED ON VIDEO SIGNAL PROCESSING BY USING GABOR WAVELET. 4(3), 3649-3656.

Ciputra, A. (2018). DENGAN ALGORITMA NAIVE BAYES DAN EKSTRAKSI FITUR CITRA DIGITAL. 9(1), 465-472.

Nurhayati, O. D. (2015). Mengenali Jenis Telur Ayam Biasa Dan Telur Ayam Omega-3. Jurnal Sistem Komputer, 5(2), 5-8.

Permadi, Y., \& Murinto. (2015). APLIKASI PENGOLAHAN CITRA UNTUK IDENTIFIKASI KEMATANGAN MENTIMUN BERDASARKAN TEKSTUR KULIT BUAH MENGGUNAKAN METODE EKSTRAKSI CIRI STATISTIK. Informatika, 9(1), 1028-1038.

Wati, R. R. (2015). Digital Repository Universitas Jember. In Kemitraan Pengelolaan Ekowisata Mangrove Blok Bedul.
Yendri, D., Teknik, J., Politeknik, E., Padang, N., Komputer, J. S., Informasi, F. T., \& Andalas, U. (2012). Implementasi Web Camera Sebagai Visual Inspection Otomatis Untuk Proses Pemutuan Ukuran Dan. Jurnal Elektron, 4(2), 57-66.

\section{PROFIL PENULIS}

Rizky Ade Safitri lahir di Sintang pada tanggal 24 Januari 1997. Menyelesaikan studi Diploma 3 pada tahun 2017 di AMIK BSI Pontianak Program Studi Manajemen Informatika dan Strata 1 pada tahun 2018 di Universitas BSI Bandung program studi Sistem Informasi.

Siti Nurdiani lahir di Pontianak pada tanggal 09 Maret 1996. Menyelesaikan studi Diploma 3 pada tahun 2017 di AMIK BSI Pontianak Program Studi Manajemen Informatika dan Strata 1 pada tahun 2018 di Universitas BSI Bandung program studi Sistem Informasi

Dwiza Riana lahir di Indonesia pada tahun 1970. Menyelesaikan gelar Sarjana pada bidang Matematika di Universitas Sriwijaya, Indonesia, Magister Manajemen di Universitas Budi Luhur, Indonesia, Magister Ilmu Komputer di Universitas Indonesia dan $\mathrm{PhD}$ di bidang teknik Elektronika Informatika di Institut Teknologi Bandung, Indonesia. Penelitiannya di bidang Ilmu Komputer, Teknik Biomedis, Data Mining, dan Sistem Informasi.

Sri Hadianti lahir pada tahun 1994. Menyelesaikan gelar sarjana di bidang komputer di Universitas BSI Bandung. Minat penelitiannya di bidang Image Processing, Data Mining dan Sistem Informasi. 